\title{
Urbanization and Regional Imbalances in Indonesia
}

\author{
Saratri Wilonoyudho, R.Rijanta, Yeremias T.Keban, and Bakti Setiawan
}

Received: September 2016/ Accepted: January 2017 / Published online: December 2017

(c) 2017 Faculty of Geography UGM and The Indonesian Geographers Association

\begin{abstract}
The level of urbanization that occurred in Indonesia at this time is remarkable that causes the growth of cities very rapidly. The growth of cities is mainly due to various reasons such as the capitalization process, regional enlargement/reclassification, as well as migration from rural to urban. The growth of cities leads a lot of problems like environmental degradation, traffic congestion, poverty, crime and other social conflicts. Such a rapid rate of urbanization is a reflection of the inequity between rural and urban development. Lack of employment opportunities in the village causes the population to go into town to find work. The imbalance of development that occurs is a result of implementing a liberal economic system that only emphasizes growth, while on the other side of the agricultural sector is not paid any appropriate attention. The farmers are at a very weak and do not have a good bargaining position, with the exchange rate is very lame. The imbalances of development do not only occur between rural and urban, but also between Java and the outside of Java, and between western and eastern Indonesia regions. This imbalance should be found a solution, with good management and equitable development, including the political will to reform the economic system in favor of the Indonesian people.
\end{abstract}

Keywords: level of urbanization, urban growth, the lack of employment opportunities in villages, the economic system, regional imbalance

Abstrak: Tingkat urbanisasi di Indonesia sangat cepat akibat dari proses kapitalisasi, reklasifikasi, maupun karena migrasi. Urbanisasi banyak membawa akibat buruk seperti penurunan mutu lingkungan, kemacetan lalu lintas, kemiskinan, konflik sosial dan sebagainya. Urbanisasi merupakan akibat dari ketidakseimbangan antara pertumbuhan ekonomi di desa dan di kota. Kelangkaan kerja di desa menyebabkan terjadinya migrasi. Namun ketidakseimbangan tidak hanya antara desa dan kota, namun juga antara Pulau Jawa dan luar Pulau Jawa, serta antara Indonesia bagian Barat dan Indonesia bagian Timur. Ketidakseimbangan ini harus dicarikan pemecahannya, di antaranya melalui perbaikan manajemen pembangunan, pemerataan, serta mereformasi sistem ekonomi nasional, dari yang berpihak kepada pemodal besar ke ekonomi kerakyatan.

Kata Kunci : tingkat urbanisasi, pertumbuhan kota, kesenjangan kesempatan kerja di desa, sistem ekonomi, kesenjangan antarwilayah regional

\section{Introduction}

Data of BPS (Badan Pusat Statistik/Central Board of Statistics) of the Republic of Indonesia [1997, 2007] showed that the proportion of urban population in Indonesia continued to expand, i.e. $22.3 \%$ in 1980 to $30.9 \%$ in 1990 and rose sharply to $43.1 \%$ in $2005 ; 55 \%$ in 2013. If the level of urbanization was calculated as well, it was noticed that it had a remarkable improvement. According to BPS [1982,1992, 2002], in 1980 there were only 8 provinces with urbanization rates above 20\%, namely North Sumatera, Riau, South Sumatera, DKI

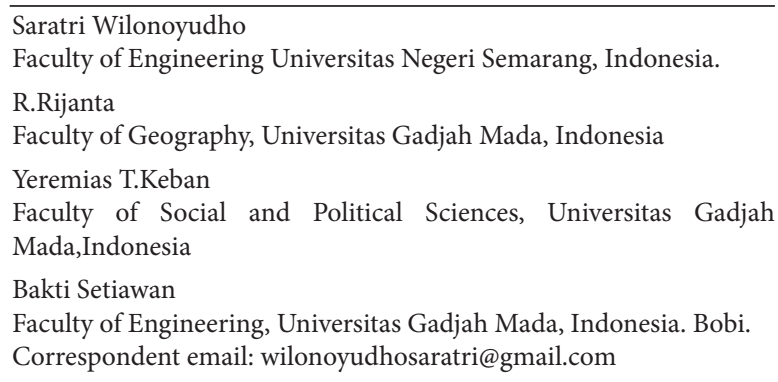

Jakarta, West Java, Yogyakarta, South Kalimantan and East Kalimantan. In 2005 that number had increased into 21 provinces, even the 11 provinces among had urbanization rates above $40 \%$ urbanization namely North Sumatra, Riau, Bangka Belitung, DKI Jakarta, Banten, West Java, Central Java, Yogyakarta, East Java, Bali, and East Kalimantan.

The increase of urban population was in stark contrast compared with a decrease in total population in Indonesia. The increase of urban population in the period 1970-1980 was 4.6\% per annum and increased to $5.36 \%$ per annum in the period $1980-1990$, while total population growth rate declined from $2.34 \%$ per annum in the period 1970-1980 into $1.97 \%$ per annum in $1980-1990$, even dropped again to $1.37 \%$ per annum in 1990-1994. This data shows that the growth of cities in Indonesia is very fast. The increased urban population in the years 1990-1995 due to migration and reclassification, and the figure reached 63\%. Meanwhile, when viewed from the location of the island, then the proportion of urban population in Java reached the 
number of $70 \%$ and outside of Java, only $26 \%$. That number is relatively constant until present [BPS, 1982, 1992, 2002].

The cities that dominate the large number of people living in are Jakarta, Bandung, Medan, Surabaya, and Semarang. Index primacy of Jakarta against four other major cities is still high which is 1.51 in 1980, and 1.51 in 1990, and 1.41 in 2005 . This means that Jakarta still dominated among the cities in Indonesia in terms of population size and economic power, although the index number decreased. Issues that need to be explained is that if the primacy index was only focused on the problem of population or whether there are symptoms of economic domination of Jakarta on the other big cities in Indonesia? This question was important to answer because there was no exact formula that the city had a population of many will be "parasitic" and vice versa. For example, large cities like Sao Paulo, Bogota and Calcutta did not show symptoms of parasitic, opposite a small town like Kathmandu, Lome, Banjul, Asuncion, in fact, were primates [Keban, 1996].

Other data BPS [2006] showing the very rapid growth of cities in Indonesia, which continued to increase throughout the year. Java still dominated the high level of urbanization; Nevertheless, Sumatera, Kalimantan, and Papua islands also showed a high level of urbanization. This is due to the number of rural populations on the islands were relatively small, so that by the number of cities a few others, thus the increase in urban population would generate high levels of urbanization. Therefore, it was not surprising that the level of urbanization in East Kalimantan, Riau Islands was very high, respectively $79.3 \%$ and $56.4 \%$ in 2005 .

In general, the growth of cities in Java still showed the formation of spatial patterns that lead to the form of corridors, such corridors of Semarang-Jakarta through Cirebon, Semarang-Yogyakarta, and Surabaya-Malang. Small towns between the two cities or more generally almost fused, thus it could be said that the small towns' roles were weakened. McGee [1971,1991] called it a phenomenon of "desa-kota (village-city)", and this phenomenon can be observed within the framework of "region-based urbanization" and not as a "city based". Therefore the cities in Java such as Jakarta, for example, now has "integrated" with Depok, Tangerang, Bogor, Bekasi ("Jabodetabek") and formed a "megapolitan". Similarly, other major cities like Semarang "integrated" with the area behind it called "Kedungsepur" (Kendal, Demak, Ungaran,Semarang,Purwodadi), "Megapolitan” Surabaya named "GerbangKertasusila" (Gresik, Bangkalan, Mojokerto, Surabaya, Sidoarjo, Lamongan), and also Megaurban Bandung Raya. According to Jones [2003] internal migration and urbanization is a one of the strategic recommendations of the Plan Action in the Fifth Asian and Pacific Population Conference.

\section{The Methods}

This research is trying to uncover the meaning of urbanization phenomena by utilizing the numerical data or information of survey result from BPS (Central Bureau of Statistics of the Republic of Indonesia) or other related institutions. The understanding toward these data and information is fairly done and, without any manipulation, arranged through some experiments or tests. In other words, it tends to be a qualitative research [Nasution, 1988]. This research, in order to be much comprehensively, will fuse the quantitative research and numeric [Brannen, 1997]. The data or information collected will be analyzed after being correlated and gathered with the facts and other data; besides it will be supported by the data triangulation. Seeing the model used by Miles and Huberman [1992], content analysis model is used to analyzed the substance of any documents related to spatial policy, spatial planning of the city, and some other population prudence.

\section{Result and Discussion}

The growth of cities seems to occur more rapidly in Java, and the cities that are formed will be more led to the form of a "region-based urbanization," instead of "city based," therefore the issue of regional imbalance development should also be a central point in the future development planning. In regional development, the issue of justice always becomes a hot talk, especially related to the problem of "regional imbalances". Until recently the issue of the interregional gap centered on the gap between rural and urban, between the Indonesia Western Region (Kawasan Barat Indonesia/KBI : Java, Sumatera, and Bali) and Indonesia Eastern (Kawasan Timur Indonesia/KTI : Kalimantan, Sulawesi, Maluku, Nusa Tenggara and Papua), as well as between Java and outside Java.

There are a lot of indicators used to show that a region is considered more advanced than other regions. Hill [1990,1998], for example, mentioned static indicators such as HDI (human development index), the Physical Quality of Life Index), and the rate of GRDP (gross regional domestic product). Jakarta, for example, has a GRDP much larger than the other provinces and shows the "dominance" of the cities of Jakarta and elsewhere in Indonesia. This fact also shows that the development of an area is affected by an important factor, i.e. the regional development investment; while the regional imbalances will occur if the interregional investment allocation is also lame [Aziz, 1985].

Resource endowment theory says that economic development depends on the natural resources and the demand for commodities produced from those resources [Perloff and Wingo, 1961]. The theory of export base or the theory of economic base which developed by North [1955] essentially said that the long-term regional growth depends on the activities of its export 
industry. In other words, if external demand for goods and services produced and exported from the region were high, this area was known to have good strength. Furthermore, the neoclassical growth theory developed by Richardson [1973] continued the previous theory of Borts [1960]. According to this theory of economic growth in a region associated with the three important factors, i.e. labor, capital availability, and technological progress.

On the other hand, Hirschman [1958] says that development strategy should be centralized to some sectors and then spread in "backward linkage" and "forward linkage". If the leading sector linked and distributed to the next, from one company to another company, there will be the effect of good growth. But clearly, the lack of backward linkages is caused by the lack capital many farmers face in developing countries. Generally, farmers are highly depended on the agricultural products from abroad, such as medicines and fertilizers. In addition, many modern industries unrelated to agriculture products - forward linkage. Capital-intensive industries overbear the network from upstream to downstream.

Meanwhile, according to Myrdal [1975] there are two forces at work in the process of economic growth, i.e. the effect of negative feedback (backwash effect) and the spread effect. Both these forces are used to indicate the spatial consequences of economic growth centered, whether negative or positive. Gunnar Myrdal argued that whatever the reasons are for expansion of growth center, when the accumulation of internal and external economic expansion materialized, it will fortify its growth in other places. According to Peroux [as cited in Stohr and Taylor, 1981], growth pole concept focuses on: 1). interactions among sectors of industry and spatial development process, 2 ). the importance of the entrepreneurial attitude of innovation, 3). the dominance of the corporate sector will be oligopolistic, affects the activity of the provision (suppliers and clients), 4). accelerating urbanization expansion of several centers of economic polarization, agglomeration, infrastructure, etc. is the main problem of the growth poles.

Although big cities in the more densely populated Java island, in fact, if examined more deeply, precisely the rate of urban population growth in Java was relatively low when compared with the outside of Java. The growth of urban population on the island of Java in the period 2000-2005 is only $6.77 \%$ while the island of Kalimantan and Papua, respectively $11.68 \%$ and $16.83 \%$ [BPS, 2002, 2007]. From the fact is expected in the coming years, the pattern of urbanization in Indonesia will be more likely to widen and not be focused on the big cities only. This prediction is also based on some facts, that the big cities, especially in Java, including Jakarta, Bandung, Surabaya and Semarang, has been relatively crowded so that there is no any possibility to accommodate more people, so it must be spilling into the suburbs which is in line with McGee [1991] said the phenomenon of "creating a new city."

Land use changes in Greater Jakarta area are very dynamic because of the need for settlements and converting agricultural land. Land use which has potential inconsistency in the future are requires for land use control in this region. The result shows that land use consistency with policies raise until 97,4\% but only $93.9 \%$ without control by policies [Kurnianti, Ernan Rustiadi, dan Dwi Putro Tejo Baskoro, 2015]. Land use change by human activities, expressed by urbanization, and the result shown that the temperature condition, both air surface and land surface temperature, were changed [Wibowo, 2013]. In the Same case, in Nigeria, that climate change is posing increasing challenges for cities placing greater stress and impacts on multiple social and biophysical systems, including urban infrastructure, water and energy demand simultaneously, followed by a strong global trend towards urbanization of urban poverty. The study concluded that climate change has impacted greatly on virtually all the socio-economic aspects of man [Samson, Olorunnimbe Rafiu O, 2011].

On the other hand, the condition outside of Javasuch as Kalimantan, Bali, Nusa Tenggara, Papua, Maluku and Sulawesi-is merely one of two secondary cities. The result can be clearly expected, i.e. the secondary cities outside Java have a range of services a wider area compared with the cities in Java. These conditions cause the level of services of those cities is less efficient and effective. The dominance of Java appears in this case, as seen in large numbers outside of GDP compared with Java.

Generally, the crisis of urban development in Indonesia is inseparable from the problems of national development. This leads to the prolonged crisis in urban development planning. This crisis initially stems from the many collisions or conflicts of the aspirations and conflicts of interests among individuals, or between individuals with other groups such as bureaucracy and government agencies as well as with the owners of big capital. As an illustration, one side of town can be inhabited by a crowded of people. Residents are generally low-income communities that make up the slum, with very poor environmental conditions. These slum areas are generally far from urban services like drinking water, electricity, shower facilities, laundry, and toilet, manufacturing waste systems, health facilities and so forth. Data of Indonesia Demographic and Health Survey or Survai Demografi dan Kesehatan Indonesia/SDKI 2007 [BPS, 2008] showed only 65.7\% of urban population has toilets with septic tanks, and only $42.7 \%$ who use drinking water from protected wells and plumbing.

In the same case, the urbanization in India and condition of urban slums in terms of water, 
sanitation, electricity, garbage collection and health care, and education which are supposed to be basic minimum needs for the slum dwellers. India is going through the process of rapid urbanization because of industrialization like other third world countries. At the all-India level about $30 \%$ of slums were located in open spaces or parks, $23 \%$ along nallahs or drains, and $9 \%$ along railway lines. These include respiratory infections as well as diseases due to nutritional eficiency, both of which are associated with poverty, overcrowding and poor environmental conditions [Chimankar, 2016].

\section{Gaps Urban-Rural or Village-City}

Earlier it was informed that regional development is closely linked with political-economic system of a country. It is also agreed by Hill $[1990,1998]$, that the central government policy will be a decision to develop the region anywhere, and will "sacrifice" other areas. During the Soeharto Governmental called New-Order, it was taken to develop a region embraced the concept of growth poles, and this has caused casualties, the imbalance of development. This concept by Douglass $[1995,2000]$ was done by allocating a high investment in the industrial sector in a big city center. The hope was to spread economic growth and generate development in the surrounding areas ( a spread effect and the trickledown effect). The assumption was that the goods produced and exported to other centers metropolitan to become "engines of development". Lack of attention to such complex phenomena would lead to an understanding of urbanization in Indonesia incomplete because it was merely observed in terms demographic. According to Malamassam [2016], migration preferences by young people in Indonesia, although youth migrants are only a small part of youth population in Indonesia, it is still important to understand the trend and pattern of their movement. This is because youth migration not only reflects the level of development area of origin and destination areas, but also illustrates brain and skill flows among regions in the country.

The history of development in Indonesia shows that the various regulations issued by the government more visible as a form of "applying" the theory of economic growth. Growth pole concept assumes that industrialization is seen as a magic recipe for reducing poverty, underdevelopment and unemployment in developing countries. With industrialization, employment opportunities expected to arise and be able to accommodate the overflow of work from the agricultural sector. In developing countries it is assumed there are products that can be driven agricultural productivity so that it will reach its highest level in food production, expand employment opportunities and income in most communities, particularly in the subsistence level.
From this point it is expected to grow small and medium business enterprises farm, capital movement, credit, technology with research. By encouraging the institutional framework in the rural areas, it is expected to drive regional growth. Furthermore, through integration into the market system is expected to receive benefits as follows: 1). growing economies of scale that its effects can spread in rural areas; 2). helping organize the rural economy in hinterland area to offer or supply, market and administrative; 3 ). there must be innovation for entrepreneurs come into view, 4). there is investment return that can be used for future development.

In fact, the growth pole strategy is not suitable in developing countries such as Indonesia, because there is dualism between agriculture and industry sectors, as well as penetration of global capitalism. On the one hand the agricultural sector experienced a lot of obstacles because of the agricultural land-especially_in Java is very narrow and a lot of fragmentation or inheritance. On the other hand, the industrial sector is very capital intensive and oriented to import substitution. As a result, only a skilled workforce that can enter the industrial sector. The existence of urban bias of this kind lead to the growth of the informal sector, due to overflowing of labor from the agricultural sector is not much that can be accommodated in the industrial sector. The theories of Boeke [1961] about the duality of economic sectors and from Geertz [1963] on agricultural involution much describe the poverty and employment opportunities in rural areas.

On the other side of Popkin [1979] studies show that traditional institutions are not effective in ensuring rural subsistence needs of small farmers. In the traditional community systems, externalities of production and cost information appear so high, so the use of non-market institutions by the rural elite was assessed to give a big advantage. In straightforward, Popkin also found, that the rich farmers generally tend to perform exploitative relations, by exploiting its status in political power or social status.

This fact is also strengthened by the observation of Scott [1976] of the farmers in Southeast Asia, which is generally characterized by law exchange balance. The evidence that can be noted as Collier [1981] suggested how socio-economic polarization and class differentiation had occurred in many rural areas in Central Java, according to him it was because of technological changes. By utilizing technology, vast landless peasants are trying to maximize profits without hiring a lot of human labor. This example shows how socio-economic polarization can occur because of unequal land ownership structure. Through the commercialization of agriculture on the one hand, and the limited agricultural land on the other hand, have much serious impact in rural areas. Meanwhile, the great population explosion added aggravates the situation, such as the limited job opportunities in rural areas. 
Increasingly weakening the agricultural sector was shown by data from BPS [2005], i.e. the number of landless farmers (have less than 0.25 hectares) increased by $2.6 \%$ per year; from 10.8 million farmers in 1993 to 13.7 million in 2003. The number of farmers' lands declined from 0.5 ha per farmer in 1993 to only 0.3 ha per farmer in 2003. Peasant food could only satisfy $30 \%$ of the needs of his family if the land is cultivated only one hectare. Though the amount of food farmers was $72 \%$ of the total farmers there! From this condition, it is also reasonable if the contribution of the agricultural sector, excluding fisheries and forestry-only about 10,23 $\%$ during the period of 2010-2014 with annual growth rate between 3,47\% to $4.51 \%$ [Rencana Strategis Kementerian Pertanian 2015-2019]. On the other side of the agricultural sector absorbed 43 million workers who are $45 \%$ of the total workforce in this country. If the data has recently been showing this condition, especially after ten years have passed, so now the situation is expected to get worse because the land is a resource that cannot be updated. The reduced contribution of the agricultural sector is strongly suspected was the result of an impartial policy to prioritize among farmers and industrial sectors.

It seems clear that the agricultural sector contribution to GDP fluctuated, but tended to decline. Preliminary figures in the first half of 2013 the percentage of the agricultural sector is in the range of numbers that mean 14.43 percent decrease from the 15.19 percent figure in 2003 [BPS Sensus Pertanian 2013]. Hence, the idea of empowerment of rural communities continues trolling, for example, through the revitalization of agriculture. The idea of revitalizing agriculture will intersect with agrarian reform. Agrarian reform has long been a warm conversation around the world. Even the United Nations in "Progress in Land Reform, NY Fifth Report, 1970, Vol. III states:

"Agrarian reform ... .. to cover all aspects of institutional development Including land reform, tenure production and supporting services structure and related institutions, Such as local government, public administration in rural areas, rural education and rural social welfare institution, and so forth."

From this point, agrarian reform should be political will. The simple reason given is because the essence of agrarian reform is how to provide the basis for a better life than those who first felt the consequences, if their production equipment in the form of land forcibly taken over by another party without agreed agreement. Some do use the term land-reform, even in neo-classical thinking maps (rational Peasant), many made by donor countries in various countries such as Latin America, India, Korea, Taiwan, and Japan. The ideas of landreform tend to focus on a fair distribution of land, in this way the productivity will increase.
But it seems that land-sharing not to solve the problem, because the root problem in the farming communities of developing countries is a matter of capital. In other words, the revitalization of agriculture is not simple. Issues such as: lack of capital of small farmers, the shrinking of land ownership, price uncertainty, farmers lame exchange with industrial products (terms of trade), difficulty of access to information and technology (appropriate) for farmers, interruption of production networks among farmers with industrialists, etc., is a series of examples of how weak the farmers are. According to Effendi [1991] in Klaten, Jatinom shows that if there was an increase income of farmers, it increased demand for goods in household consumption. Improved access to infrastructure such as roads and transport services even easier for urban industry to go and sell directly to farmers. This fact can be deadly industrial development in the countryside so close opportunities

In other words, the revitalization of agriculture also involves the revamping of a capital reform as well as rural institutions the United Nations defined above. If someone, for example, says that subsistence farmers will be helped if they were given education provision, infrastructure improvements (roads, irrigation), and information technology, the fact of the above study shows there was the shortcoming by blockage of the opportunity for the small farmers to enjoy the results as it is covered by institutions in rural areas has not been effective.

Brief sketch is just wanted to show that there is imbalance between rural and urban development. When agricultural land owned by a few people, then the big cities tend to be parasitic. Conversely, if agricultural land is distributed uniformly then it becomes weak parasitic nature [Keban, 1996]. Cities in developing countries including Indonesia are expected to play an important role in regional development. Therefore, ideally between small towns and big cities are integrated in a harmonious pattern of spatial economics.

\section{Development Imbalances of Western and Eastern Indonesia Regions}

Having been described previously that the level of urbanization in the Western Region of Indonesia (Kawasan Barat Indonesia /KBI) was higher when compared with the level of urbanization in Eastern Indonesia (Kawasan Timur Indonesia/KTI). This fact indicates the existence of regional development imbalances between the Western Regions of Indonesia $(\mathrm{KBI})$ and Eastern Indonesia (KTI). GDP in Java and Sumatra (KBI) is much higher when compared to GDP in eastern Indonesia such as Kalimantan, Papua and Sulawesi. Similarly, the percentage of urban population between Java, Sumatra and Papua, Kalimantan, Sulawesi, also showed the rapid development in the 
KBI. In Papua, for example, the percentage of urban population in 1980 only $1.23 \%$ and in 2005 to $1.32 \%$, while in 1980 the percentage of urban population in Java has more than $69 \%$ in Sumatra and more than $16 \%$ [BPS, 1982, 2007].

As already indicated in section on literature review, the study by Nurzaman [1997] showed that the gap between the two regions does not occur in all cases, but only in the economic field. Indicators used in the economic field are: 1). total income per capita, 2). growth in per capita income, 3). labor force participation rate, 4). percentage of value added manufacturing sector of total provincial GDP, 5). percentage of workers working in the manufacturing sector compared to total provincial workforce; 6). the level of foreign investment and domestic cumulatively; 7). percentage of population living in urban areas; and 8). The road length/10.000 square $\mathrm{km}$ of province. In the social field, the gap shown by the fact, with indicators such as: 1). Physical Quality of Life Index, 2). number of primary school pupils compared to the total population, 3). percentage of college-educated workforce or university, 4). elementary School teacher ratio per 10,000students, $5)$. the ratio of doctors per 10,000 population, and 6). the ratio of hospital beds per 10,000 population.

But if it were broken down in every economic sector, then the gas sector, oil and mining companies made major contributions in several provinces of South Sumatra (oil and coal), Papua (copper, gold), Sulawesi (nickel). While the financial services sector, banks, manufacturing, building, construction, transportation, communication, etc., was highly concentrated in developed provinces such as Jakarta and Java. Distribution of percentage of GDP Jakarta around $16.06 \%$ in 2007 and in the same year NTT, NTB, West Papua and Papua each only0.54\%, 0.95\%, 0.29\%, and $1.57 \%$ [BPS, 2009]. This data shows how much imbalance the more real, and for more complete again, will show that the gap area looks really real.

BPS Data [1998] showed that within 10 years before the 1997 economic crisis, manufacturing industry non-oil-and-gas grew at an average 12 percent per year, and this number was 5 points higher than economic growth as measured by Gross Domestic Product (GDP). Whereas in the period 2004-2008, the growth of manufacturing industry non-oil-and-gas declined into 5.6 percent per year, which meant lower than GDP growth reaching 5.7 percent per year. In other words, the contribution of non-oil and gas manufacturing sector to GDP declined since the economic crisis. Along 2005-2009 more banks expected to channel funds to the property sector was "booming" compared to the industrial sector, due to data released by Bank Indonesia [Kompas, 20/10/2009] mentioned that in 2008 the industrial world only got a small bank loan as much as 16 percent, whereas in 1985 nearly 40 percent of bank credit channeled to the manufacturing sector.
Along the same time, symptoms of de-industrialization coincided with a shift in the role of the manufacturing sector to the informal sector. This phenomenon was allegedly associated with the behavior of banks that prefer lending in the services sector, consumer finance, and property, which is considered to have a smaller risk and the payback period is relatively fast when compared to distribute in the industrial sector.

Thus the role of manufacturing industries was shifted by the services sector-especially in the urbanmodern services. According to records Kompas (20/10/2009) from the discussion entitled "Vision 2030, Industry Sector Development" organized by the Indonesian Chamber of Commerce and Industry (Kadin), in 2008 the manufacturing industry contributed 1 point to 6.1 GDP growth, much more lower than the average during 2000-2008 which contributed 1.4 points to 5.7 percent GDP growth. The role of manufacturing industries to increase the additional value reached its peak in 2004 with a contribution of 28.1 percent and fell to 27.1 percent in 2007 , and slightly rose to 27.9 in 2008.

In addition to its investment constraints, the slow growth of industrial sector was also due to the fragility of the industrial structure, especially the weak link between downstream and upstream industries, including small industries, medium and large industries, as well as dependence on raw materials that most still have to be imported. Externally, obstacles arise from the small supply of energy needed by the industry (oil, gas, and electricity). Channeling these energy policies generally state that is sometimes not in line with the policy of the industrialists, such as oil and gas energy was exported, while domestic demand is not fulfilled. Besides bureaucratic behavior, especially in customs clearance (customs and excise) are also often circuitous to hamper efficiency. This is compounded by inadequate infrastructure, such as port capacity is minimal or the narrow road and the number of levies on the streets.

In connection with the phenomenon of deindustrialization is the fears of unemployment, because the service sector growth is usually not followed by an increase in the absorption of workers. It is still quite encouraging; the results of the discussion also noted the value of Indonesian exports in 2008 from non-oil sector, 82 per cent of which is the form of product production. Because of various obstacles mentioned above must be overcome for industrialization is able to absorb the labor force and led to the welfare of the people. Hope this will be more fair if between downstream and upstream industries can be established, as well as between small, medium and large, including with farmers who produce food. Another thing to consider is the efficiency of the industry so that they can pay a decent wage and be able to process wastes that endanger residents. If this is not addressed, then there are many cases protests. 


\section{Conclusion}

The regional imbalances can be overcome by avoiding the dominance of the core city to the area behind it (hinterland). This effort is one way to make the area behind the counter magnet causing the development of harmony between the regions. The hope is the urbanization of the area surrounding the city center can be reduced. The city core has relatively complete infrastructure, such as airports, container ports, financial institutions, industrial and services sectors, and so is expected to further disseminate the results of development (a spread effect and trickledown effect), for the major city not potential to become "parasites" that exploit the area behind it.

From these two things, close cooperation between regions must be embodied in the vision, mission, and the real action in the field because of the development and growth of the city seemed not recognize administrative boundaries. In other words there is a kind of joint planning towards an integrated regional development program that is clear and reasonable in all aspects. Therefore there are at least 5 things that must be considered in co-operation between regions, i.e. efficiency and optimization of benefits, interregional integration, harmony and balance, efforts to help each other and interdependent and mutually beneficial cooperation;

Another thing that must be realized, the coordination of development that does not mean enlarging the metropolitan area as its center, and also need to realize this cooperation will not automatically be able to cope with urbanization, because urbanization is also associated with the policy at national and even international level, for example because of the related dominance of world capitalism. In this coordination is also necessary to distinguish between administrative term development planning and administrative terms. This means that for things that are detailed, each region has its own authority, because they have their own uniqueness and most understand the problems of its own. In other words, cooperation should be only at the level of planning and implementation of programs that have regional implications together.

The regions are less developed are encouraged by the mobilization of the entire institution, both from the universities, NGOs, the research world, small and medium businesses and large employers, financial institutions, regional, national financial institutions, as well as the ability of the officers are skilled and have a vision of the future mission clear. All are supposed to be run on a closely network.

\section{References}

Aziz, Iwan Jaya. (1985). Pembangunan Daerah dan Aspek Alokasi Investasi Antardaerah. Prisma No.6. pp. 3-21. (in Bahasa Indonesia)
Boeke,JH. (1961). The Theory of Dualism in Wertheim (eds) The Concept of Dualism in Theory and Policy. Amsterdam, W Van Hoeve Publisher Ltd. pp. 165-193.

Borts, George H.(1960). The Equalization of Returns and Regional Economic Growth American Economic Review.50. pp.319-347.

BPS, (1982). Sensus Penduduk 1980. (in Bahasa Indonesia)

BPS, (1992). Sensus Penduduk 1990. (in Bahasa Indonesia)

BPS,(1997). Survai Antar Sensus 1995. (in Bahasa Indonesia)

BPS,(1998). Produk Domestik Bruto Indonesia. (in Bahasa Indonesia)

BPS,(2002). Sensus Penduduk 2000. (in Bahasa Indonesia)

BPS,(2005). Survai Sosial Ekonomi Indonesia. (in Bahasa Indonesia)

BPS,(2006). Survai Angkatan Kerja Nasional. (in Bahasa Indonesia)

BPS,(2007). Survai Antar Sensus 2005. (in Bahasa Indonesia)

BPS,(2008). Survai Demografi dan Kesehatan Indonesia 2007. (in Bahasa Indonesia)

BPS,(2009). Produk Domestik Bruto Indonesia. (in Bahasa Indonesia)

BPS, (2013). Sensus Pertanian. (in Bahasa Indonesia)

Brannen,J.(1997). MemaduMetodePenelitian Kualitatif dan Kuantitatif Terjemahan Nuktah Arfawie Kurde, Imam Syafei, Noorhadi AH. Yogyakarta : Pustaka Pelajar. (in Bahasa Indonesia)

Chimankar, Digambar Abaji, (2016).Urbanization and Condition of Urban Slums in India. Indonesian Journal of Geography. Vol. 48 No.1, June, pp. 28 -36 .

Collier, William. (1981). Agricultural Evolution in Java : The Decline Share Poverty And Involution" in Agricultural and Rural Development in Indonesia. Boulder, Col : Westview Press .

Douglass, M. (1995). Global Interdependence and Urbanization : Planning for the Bangkok Megaurban Regions in McGee,T.G and I.M.Robinson (eds) The Megaurban Regions of Southeast Asia. Vancouver, The University of British Columbia Press pp. 45-77.

Douglass, M., (2000). Megaurban Regions and World City Formation : Globalization, the Economic Crisis and Urban Policy Issues in Pacific Asia" Urban Studies 37 (12). Pp. 15-36.

Effendi, Tadjuddin Noer.(1991). The Growth of Rural Non-Farm Activities at the Local Level : A Case Study of Cause and Effects in a Subdistrict Of 
Upland Central Java. The Flinders University. Ph.D Thesis. Unpublised.

Geertz, Clifford, (1963). Peddlers and Princes : Social Change and Economic Modernization in Two Indonesian Towns. Chicago : The University Of Chicago Press.

Hill,Hal.(1990). Indonesia`s IndustrialTransformation Part I. Bulletin of Indonesian Economic Studies. Vol. 26 No.1. pp. 79-120

Hill, Hal.(1998). The Challenge of Regional Development in Indonesia. Australian Journal of International Affair 52, No.1.

Hirschman,A.O.(1958). The Strategy of Economic Development. New Haven : Yale University Press.

Jones, Gavin. (2003). The Fifth Asian and Pacific Population Conference : Towards A Repositioning of Population in the Global Development Agenda? Asia-Pacific Population Journal Vol.18. No.2. June. pp.21-39.

Keban, Yeremias, T. (1996). Migrasi Internasional : Kecenderungan, Determinan, Dampak dan Kebijakan. Kertas Kerja Pelatihan Mobilitas Penduduk Tanggal 11 - 23 Desember 1995 di Pusat Penelitian Kependudukan UGM. (in Bahasa Indonesia).

Kompas, The Daily, 20 October (2009).

Kurnianti, D.N, Rustiadi, E and Baskoro, D.P.T.(2015).Land Use Projection for Spatial Plan Consistency in Jabodetabek. Indonesian Journal of Geography, Vol. 47, No.2, December, pp.124 - 131

Malamassam, Meirina Ayumi, (2016). Youth Migration in Indonesia: Decision to Move and to Choose of Destination Areas. Indonesian Journal of Geography. Vol. 48, No.1, June, pp.62 - 71.

McGee, Terry. (1971). The Urbanization Process in the Third World Exploration In Search of Theory. London : G.Bell and Son Ltd.

McGee, Terry. (1991). The Emergence of Desa Kota Regions in Asia. Dalam N.Ginsburg, B.Koppel and TG McGee (Eds) The Extended Metropolis : Settlement Transition in Asia. Honolulu : University Of Hawaii Press.

Miles, Mattew B. and Huberman, Michael. (1992). Qualitative Data Analysis. Jakarta : Indonesian University Press.

Myrdall, Gunnar. (1975). Economic Theory and Underdevelopment Region” Duckworth, 26.

Nasution,1988. Metode Penelitian Naturalistik Kualitatif. Bandung : Tarsito.

North, Douglass C.(1955). Location Theory and Regional Economic Growth. Journal of Political Economy.LXIII.June. pp. 243-258.
Nurzaman, Siti Sutriah. (1997). Tinjauan Kesenjangan Wilayah di Indonesia. Jurnal Perencanaan Wilayah dan Kota. ITB. Vol. 8. No.4. pp.11-21.

Perloff, Harvey and Lowdon Wingo Jr. (1961). Natural Resources Endowment and Regional Economic Growth. In Natural Resources and Economis Growth Ed, Joseph J. Spengler. Washington DC: Resources for the Future p.191-212

Popkin, Samuel. L. (1979). The Rational Peasant : Political Economy of Rural Society in Vietnam. Berkeley : University of California Press

Richardson,H.N.(1973). Regional Growth Theory. London : Mcmillan

Rencana Strategis Kementerian Pertanian 2015-2019

Samson, Adejobi Oladepo, Olorunnimbe Rafiu O, (2011).Conceptualization Of Urbanization Structure and Climate Change in Lagos Nigeria. Indonesian Journal of Geography. Vol. 43, No. 2, December pp. 181-194.

Scott, James.(1976). The Moral Economy of Peasant Rebellion and Subsistence In Southeast Asia. London : New Haven

Stohr, Water B and D.R. Fraser Taylor. (1981). Development From Above or Below? The Dialectics of Regional Planning in Developing Countries pp. 15-36, pp. 39-69, pp.123-150

United Nations,(1970). in Progress in Land Reform, NY Fifth Report, Vol. III

Wibowo, Adi, (2013).Spatial-Temporal Analysis of Urban Heat Island in Tangerang City, Indonesian Journal of Geography, Vol.45, No.2 December. Pp. 101-115. 